\title{
IRONY AND PARODY IN JACQUELINE WOODSON'S HARBOR ME: A POSTMODERNISM STUDY
}

\author{
${ }^{\text {a Winda Aulina, }}{ }^{\mathrm{b}}$ Dr. Dra. Siti Hanifa M.Pd \\ ${ }^{a, b}$ English Study Program, \\ Department of Social and Cultural Sciences, \\ Faculty of Social and Cultural Sciences, University of Trunojoyo Madura \\ e-mail: windaaulinal@gmail.com
}

\begin{abstract}
This study concerns to discuss the Irony and Parody in Jacqueline Woodson's novel entitled Harbor Me. This study is focused on postmodern theory, since the novel tells about social phenomena in daily life such as irony and parody. This study aims to disclose how irony and parody are reflected in Harbor Me novel by Jacqueline Woodson.

This study was conducted by applying a qualitative type since the data are in the form of words. The source of data in this study is Harbor Me novel by Jacqueline Woodson. The data are the utterances of the characters and the author's narration in Jacqueline Woodson's Harbor Me. In analyzing the data, the writer used three concurrent processes. They are data reduction, data display, and conclusion drawing or verification.

The result of this study found that irony and parody also as a theme in postmodernism literature. The irony and parody are used for illustrating the social condition in Harbor Me novel by Jacqueline Woodson. The characters experienced the irony as a real occurrence which is not accordance with their expectation. Meanwhile, they also experienced the parody for giving an insinuation by imitating others characters' words and attitudes. In addition, the presentation of irony and parody demonstrate the influence of theme in postmodernism. It is because the characteristics of irony and parody as the parts of postmodernism which have been stated by Lyotard in Sarup (1993).
\end{abstract}

Keywords: Postmodernism, Irony, Parody 


\section{INTRODUCTION}

Nowadays, postmodernism becomes one of the trending phenomena in society. Many people especially authors try to write or create the literary works which represents postmodernism aspects. Then, parody and irony are parts of them which are used to criticize and illustrate the real condition of social life. For instance, the parody is used in "The Daily Show program for giving recent news stories humorously. Meanwhile, the irony is used in real life as like in Ironic Times newspaper. The two aspects of postmodernism are also used by authors in their literary works. For example, David Foster Wallace uses irony in his novels as the tool to against hypocrisy (Winokur, 2007. p.33). Then, according to Hutcheon (in The Claim of Postmodern Parody by Valeria Brisolara Salomon's article,2006) William Gaddis uses parody in his work entitled A Frolic of His Own.

Further, many people use parody for making critique, mockery and humour. It also refers to a new creative work which imitate the original work. Parody uses for commenting the social phenomenon and problem by using a work. Then, the new comment as the result of parody itself (www.copyright.user.com). Meanwhile, irony refers to the moment which is not in accordance with the expectation (Winokur, 2007. p.33). Then, some authors declare the phenomenon give illustration to reader about those condition inside the novel.

In Harbor Me novel, there are some issues such as family, racism and friendship. This novel is chosen because it won National Association for The Advancement of Colored People Image Award. Then, Jacqueline Woodson writes the novel when she was traveling around the country especially in Brooklyn (www.jacquelinewoodson.com). In this study, the writer tries to analyze the parody and irony through the all characters and author's narration in this novel.

Further, the writer chooses the postmodernism theory by Jean Francois Lyotard. He stated that the central features which associated with postmodernism are irony, parody, pastiche and playfulness (Sarup, 1993. p.132). Meanwhile, this novel consists of postmodernism aspects such as irony and parody. In addition, there are also the characteristics of postmodernism which are very opposite in modernism like the importance of language in human life and encourage the rise of oppressed class.

In addition, literature itself is a part of human life. Then, it is also a kind of work that include author's imagination and real life. It can be seen while the authors of literary works always include real events. Therefore, the authors also use their imaginative efforts for making the literary works interesting.

\section{METHODOLOGY}

This study applied qualitative approach because of some reasons. Firstly, the data and source of data have natural characteristic which cannot be manipulated. Secondly, this study can be called as qualitative because the data collected are uttered by characters in Jacqueline Woodson's Harbor Me. Thirdly, the writer herself did the process of collecting, analyzing and interpreting the data (Miles, Huberman and Shadana, 2014. p.28).

According to Miles and Huberman, there are three concurrent processes in analyzing the data. They are data reduction, data display, and conclusion drawing or verification (Miles and Huberman, 1994. p.10). Therefore, the writer did the data analysis procedures by the three processes as follows: First, data were reduced by selecting the words and utterances of the characters which are appropriate to answer 
the research question. Second, the writer displayed and showed the data which answered the two questions related to the postmodernism aspects. Third, in conclusion drawing, the writer drew the conclusion related to the focus of this study.

\section{FINDINGS AND DISCUSSIONS}

\section{Irony Mechanism}

Irony in this novel was delivered by (1) showing the contrast between what is expected and what the reality is, (2) stating the opposite of what a character means; it is overstating or understating the reality.

\subsection{Stating The Contrast}

Irony in this novel is presented by stating the contrast between what is expected and what the reality is. It was found that there are seventeen data reflecting the contrast what characters expect with what they find. The irony is embedded in the characters' utterances and words.

The irony in this novel as one of problems which has been faced by the all characters. The irony is presented by six characters named Haley, Holly, Ashton, Amari, Tiago and Esteban who are not American. They are the students in America elementary school. In that school, they illustrate what they expect is not accordance with the reality.

"Our small class had come together because the school wanted to try something new: Could they put eight kids together in a room with one teacher and make something amazing? Eight special kids. Even though they didn't say it, we knew there was something different about us."

(Woodson, 2018. p.5-6)

The six characters are shocked because what they expect is not accordance with the reality. They actually have to study in a big classroom with two or three teachers but it is only a small classroom with one teacher. They understand that they are different. They could not speak English like other students in regular classroom. In addition, the six characters also feel that the illustration of those classroom only make injustice for them. Meanwhile, Haley as the main character describes that condition of the classroom is contrast with her expectation. In addition, those statements bring the assumption that nothing means what it says as postmodern irony.

\subsection{Stating The Opposite}

The postmodern irony experienced by characters do not happen once. It also happens while one character named Holly experiences a moment with Mrs. Laverne as her teacher. Mrs. Laverne tries to give a compliment while she jumped off to teacher's desk. She did it to express the disappointment related to the classroom. Meanwhile, she understood that she is a naughty kid. 
"Ms. Laverne laughed. "One day, Holly, your brain will be very useful to you."

Holly looked like she wasn't sure if our teacher was complimenting her."

(Woodson, 2018. p.17)

Mrs. Laverne's words implied something different. It implied different thing. What she intends is not to compliment but underestimate Holly. Mrs. Laverne's words like a compliment but, actually she just wants to point out the weakness of Holly. Then, in postmodernism there is a situation which people undergo something beyond their expectation or hope. It happens sometimes because what people intend have others meaning. In addition, what Mrs. Laverne is not to compliment but angry to Holly. It seems nothing what she said because, what Holly felt is not accordance with Mrs. Laverne's statement. She knows that she is one of the students who like dispute with her teacher.

\subsection{The Reflection of Parody}

\subsubsection{Parody by Imitating Others Character's Attitudes and Words}

The parody in this novel can be presented as the way to satirize by imitating the other characters' attitudes. The parody happened when one character imitates the other for making the reader understand what the speaker intention. Meanwhile, the postmodern parody does not always engage with humor. Otherwise, sometimes the parody also happened to give the sense of humor in some cases. In this novel, the parody occurred through all the characters in this novel.

The parody appears when the six characters want to satirize by imitating other characters' words and utterances. They do it because they want to deliver the intention of other characters briefly. In addition, parody also known as the issues which popular in the society for giving comic effect. In this novel, the parody can be seen in some others character's utterances below.

"Amari looked up at us. All the TV I want?!?! That was like a zombie talking. Because my dad is the king of 'Turn off the TV and read a book.' My dad is the 'I'll throw that TV out the window' kinda dad."

"You get the picture?"

"We all nodded"

(Woodson, 2018. p. 64-65)

Amari is one of the characters in this novel who experiences the parody. This is happened when he imitated his daddy's utterance. He imitates his daddy to deliver what his father want. Then, all of his friends are trying to understand it by seeing his expression. Amari illustrates his daddy when he asks Amari for reading the book. His dad does not like Amari who always watch television. It is because he does not expect that his son only does something unimportant. It also can be called as the way of satirize his friends. He knew that his friends seldom read book and always watch television like he himself. Amari imitates the words that his father says at the past time for giving the real illustration. Therefore, his friends got a picture to what Amari's daddy want. It is because Amari can imitate his daddy's words. 


\section{Irony and Parody as Postmodernism Theme}

The presentation of irony and parody demonstrate the influence of theme in postmodernism. It is because the characteristics of irony and parody as the parts of postmodernism which have been stated by Lyotard in Sarup (1993). It can be proved by two data which have been stated in the findings as follow.

Holly, Haley, Amari, Ashton and Tiago experience an irony which related to the condition of America. It can be seen while they talk over in a cafeteria. Meanwhile, their friend named Esteban cannot join with them. It is because he had been absent the whole week. Therefore, only five characters who argue about America.

"Nah, it's not", Holly said. "This is supposed to be America. The land of the free and the home of the brave".

(Woodson,2018. p.121)

Holly's expectation about America is not accordance with the real condition. It is because, the six children who are not American have to study in another classroom from American students. They cannot play with children who have white skin. That situation prove that America is not free, in this land there are some rules which make them cannot feel the freedom as like other kids. Therefore, they take an interpretation from those irony, that America is not land of the free for them.

Based on the findings above, it can be seen that the irony and parody influence the postmodernism theme in Harbor Me novel. It is because (1) irony which has been found in this novel is accordance with the characteristics of postmodern irony. The characteristics of postmodern irony are skeptical, multilayered, preemptive and nihilistic that refers to nothing means what it says. (2) parody in this novel also similar with the postmodern parody. The postmodern parody which has been found refer to borrowing the other text as like the dialog, word or utterance.

\section{DISCUSSION}

\section{Irony}

The findings of this study are in line with Lisa Colleta's study (2009) which describes that the irony in postmodernism prefer to the self-referential and cynical acquaintance. It means that the readers or audiences who read the literary works have an awareness to interpret something. Meanwhile, the irony also as a place to discover what happen in the reality and expectation. In addition, irony in postmodernism also as a denial of differences between the real and visible situation. In her study, Lisa uses The Simpson as the source of data for analyzing the postmodern irony. The irony does not always engage with what is said and what is actually happen. In her study, the postmodern irony is used for giving an entertainment through the cynicism and joke to the audiences. Those statements are similar with Jon Winokur's theory. Meanwhile, Lisa also uses the theory which has been proposed by Frederic Jameson.

Meanwhile, the findings also are in line with Elaine B. Safer's study (2015) which uses Linda Hutcheon's theory. She uses Philip Roth's novel entitled Operation Shylock as the source of data. Roth's work can be analyzed by Linda Hutcheon's theory which full of contradiction as the characterization of postmodernism. In her study, postmodern irony states that comic as a tool to support the irony. Then, it also uses as the way of problem solving in contemporary situation which has relationship with Jewish people. It is not only comic but also double irony. The double irony for 
creating a kind of characters. Then, Elaine states that Roth use the irony for challenging the readers about the characters in the fictions and the reality. Those statements are almost in line with Jean Francois Lyotard's theory (1988).

Moreover, the findings are also similar with Ramen Sharma and Dr. Preety Chaudhary's study. Their study describes that fiction in postmodernism always has relationship with the irony. Then, it has been stated by Linda Hutcheon which mentioned that literary work can be mixed with humour and playfulness concept. In addition, the serious subject in the literary work can be treated by using black humour. For instance, the story entitled The School by Donald Barthelme which use postmodern irony for illustrating the serious context in humorous way.

Based on the theory and previous study above, the position of this study is support the theory by Jon Winokur and Linda Hutcheon. It can be proved by seeing the previous study which stated that postmodern irony refers to contradiction between the reality and expectation. In addition, the postmodern irony also can be mixed with cynicism and humour feeling. Then, this study also supports postmodernism study by Jean Francois Lyotard as the basis of the theory.

Moreover, this study also develops the first and second previous study. It is because the both of them only mentioned the contrast between the reality and expectation. Meanwhile, this study discovers the opposite between what the characters said. There two kinds of stating the opposite in this study as like under stating and over stating the reality. Then, the three of previous study above mostly only discuss about the inconsistency between the expectation and reality of the characters.

\section{Parody}

The findings of this study are in line with Merve Bekiryazici study (2017) which describes that parody can be found by imitate what others characters say or do. Her analysis disclose the character in the novel borrowed some texts and characterizations of Charlotte Bronte for making people laugh. It is because Jane Eyre was one of popular novelist which people surely know her works. Therefore, Jasper Fforde imitated some Jane Eyre's texts and dialogues for making his first novel entitled The Eyre Affair. Moreover, those findings also agree with the explanations delivered by Linda Hutcheon which related to the imitation of others character's attitude and word (2000).

Furthermore, the findings of this study are almost similar with Elif Onal study (2007). His study analyzes that the parody in postmodernism has relationship with the intertextuality. Meanwhile, Linda Hutcheon as the basis theory of those analyses mentioned that parody as the tool to re-interpret one texts or works with another. Then, it also can be used as a supporting method to revise and contextualize the material of the novel in playful ways. These statements almost similar with Linda Hutcheon theory in Berthen's book (2005).

Based on the theory and previous study above, it can be proved that the position of this study is support the theory by Linda Hutcheon. Meanwhile, the findings in this study also are in line with the findings in both of previous study. It is because the parody happens by imitating the others characters' utterances and words. Then, it also occurs by comparing a normal thing and other which has comic effect. In addition, the parody also uses for re-interpreting what character's said through others character in the literary works. 


\section{CONCLUSION}

After analyzing irony and parody in Harbor Me novel by Jacqueline Woodson, it can be concluded that several characters experienced the irony and parody through their life. Irony is described as the expectation which is not accordance with the reality. It is experienced by the main character named Haley and her friends when they were in Brooklyn, New York

Further, if the teacher does not give a hope to the black students, they do not experience an ironic condition which is unhappy. It makes the students give up for doing anything. Otherwise, they expect that they can enjoy all the facilities as like other students in the regular classroom. Meanwhile, if there is no parody, the insinuation which is delivered to other people will reach the target easily. It is occurred by one of the character who fails to satirize another character by using parody. Then, if the characters do the parody, the insinuation will have function to hurt people who experience it. Moreover, they sometimes do not aware that someone satirize them. Besides that, there is the insinuation occurs through the parody which cause the misconception or misunderstanding.

\section{REFERENCES}

Berthens, Hans. (2005). The Idea of The Postmodern. London: Routledge.

Colebrook, Claire. (2004). Irony - The New Critical Idiom. London and New York: Routledge.

Dentith, Simon. (2000). Parody. London: Routledge.

Hoffman, Gerhard. (2005). From Modernism to Postmodernism - The Concepts and Strategies of Postmodern American Fiction. New York: Rodopi B.V.

Hutcheon, Linda. (2000). A Theory of Parody - The Teachings of Twentieth Century Art Forms. United States: University of Illinois Press.

Lyotard, J.F. (1984). The Postmodern Condition: A Report on Knowledge. United States: University of Minnesota Press.

Miles, Huberman and Saldana. (2014). Qualitative Data Analysis. Arizona University State: SAGE Publications, Inc.

Sarup, Madan. (1993). Introductory Guide to Post-Structuralism and Postmodernism. London : Harvester Wheatsheaf Publisher.

Winokur, Jon. (2007). The Big Book of Irony. New York: St. Martin's Press.

Woodson, Jacqueline. (2018). Harbor Me. New York: Nancy Paulsen Books. 